\title{
PENGARUH PERENDAMAN TANAH LEMPUNG LUNAK TERHADAP UJI TEKAN BEBAS
}

\author{
Christian Adi Saputra \\ Program Studi Teknik Sipil Universitas Muhammadiyah Sorong \\ Jalan Pendidikan No 27 Kota Sorong, Propinsi Papua Barat \\ Email : Ian.malastau24@gmail.com
}

\begin{abstract}
ABSTRAK
Tanah merupakan dasar dari suatu struktur bangunan. Setiap daerah memiliki karakteristik dan sifat-sifat tanah yang bervariasi.Seringkali terdapat beberapa sifat tanah yang buruk dan kurang menguntungkan untuk suatu konstruksi bangunan. Contoh beberapa sifat tanah yang perlu diperhatikan adalah plastisitas yang tinggi, kekuatan geser yang rendah, kemampatan atau perubahan volume dan kembang susut yang besar. Sangat penting untuk mengetahui permasalahan tanah tersebut, serta memberikan upaya untuk memperbaikinya. Menurut pengamatan Penulis pembangunan infrastruktur di daerah SP 4, kurang memadai khususnya untuk konstruksi jalan. Salah satu permasalahan yang dihadapi ialah kondisi tanah yang memiliki sifat yang kurang baik seperti memiliki sifat kembang susut yang sangat tinggi dan juga tanah yang sangat reaktif apabila tersiram oleh air dimana pada saat musim kemarau memiliki sifat yang sangat keras namun ketika di musim penghujan sifatnya menjadi lembek. Fenomena ini akan mengakibatkan konstruksi yang dibangun diatasnya menjadi tidak stabil.Suatu konstruksi atau bangunan sangat berhubungan dengan keadaan kondisi fisik dan mekanis tanah. Untuk memperbaiki sifat tanah merugikan yang dapat mengakibatkan daya dukung menjadi rendah, maka diperlukan perbaikan tanah yang salah satunya adalah menggunakan metode stabilisasi. Usaha stabilisasi yang banyak dilakukan adalah stabilisasi dengan menggunakan bahan. Salah satunya menggunakan bahan alternatif yaitu TX-300 yang diharapkan mampu memperbaiki sifat tanah sehingga dapat mendukung suatu konstruksi. Sampel tanah yang di uji pada penelitian ini adalah tanah lempung lunak yang berasal dari daerah Rawa Sragi, Lampung Timur. Variasi kadar campuran yang digunakan yaitu 0,4 ml, 0,7 ml, 1,0 ml, dan 1,3 ml. Pada tiap kadar campuran dilakukan perendaman selama 7 hari ,14hari ,21 hari, 28 hari.
\end{abstract}

Kata kunci : TX-300, Tanah Lempung Lunak, Kuat Tekan Bebas (UCS).

\section{PENDAHULUAN}

\section{Latar Belakang}

Tanah merupakan dasar dari suatu struktur bangunan. Setiap daerah memiliki karakteristik dan sifatsifat tanah yang bervariasi.Seringkali terdapat beberapa sifat tanah yang buruk dan kurang menguntungkan untuk suatu konstruksi bangunan. Contoh beberapa sifat tanah yang perlu diperhatikan adalah plastisitas yang tinggi, kekuatan geser yang rendah, kemampatan atau perubahan volume dan kembang susut yang besar. Sangat penting untuk mengetahui permasalahan tanah tersebut, serta memberikan upaya untuk memperbaikinya. Menurut pengamatan Penulis pembangunan infrastruktur di daerah SP 4, kurang memadai khususnya untuk konstruksi jalan. Salah satu permasalahan yang dihadapi ialah kondisi tanah yang memiliki sifat yang kurang baik seperti memiliki sifat kembang susut yang sangat tinggi dan juga tanah yang sangat reaktif apabila tersiram oleh air dimana pada saat musim kemarau memiliki sifat yang sangat keras namun ketika di musim penghujan 
sifatnya menjadi lembek. Fenomena ini akan mengakibatkan konstruksi yang dibangun diatasnya menjadi tidak stabil. Hal tersebut akan terus berulang dan bermasalah apabila tanah dibawah konstruksi tidak di stabilisasi terlebih dahulu. Penulis kemudian mengambil kasus tersebut untuk bahan penelitian skripsi. Ada beberapa langkah yang dapat diambil untuk memperbaiki tanah labil. Salah satunya adalah stabilitas tanah dengan bahan kimia. Bahan tambah kimia yang dapat digunakan diantaranya abu sawit, fly ash, kapur, semen dan lain-lain. Pada penelitian ini, digunakan bahan tambah Abu Terbang (Fly Ash) untuk stabilisasi tanah. Fly Ash merupakan satu bahan tambah (Additive) yang cukup populer saat ini untuk digunakan sebagai pengganti sebagian semen dalam campuran beton dan sebagai bahan untuk stabilisasi tanah ekspansif. Fly Ash adalah bahan limbah dari pembakaran batu bara, yang dikategorikan sebagai limbah B3(PP No. 85 tahun 1999 tentang Pengelolaan Limbah Bahan Berbahaya dan Beracun). Pada lokasi penelitian yang berada di jalan Desa Sudimanik Kecamatan Cibaliung ditemui jalan yang rusak, sehingga penulis tertarik melakukan stabilisasi tanah dengan menggunakan Fly Ash karena dalam segi ekonomis penggunaan Fly Ash sebagai zat tambahdan mengetahui nilai kekuatan tanah setelah stabilisasi pada lokasi tersebut.

\section{Tujuan Penelitian}

Penelitian ini bertujuan untuk menganalisa pengaruh perendaman tanah lempung lunak terhadap uji tekan bebas

\section{STATE OF THE ART}

Adapun penelitian terdahulu yang terkait dengan penelitian ini adalah sebagai berikut :

1. Menurut Soedarmo, Djatmiko. (1993). Mekanika Tanah 1,Malang : Kanisius. Pengaruh Penambahan Fly Ash Terhadap Nilai Kuat Tekan Bebas Pada Tanah Lempung Ekspansif Di Daerah Magetan Jawa Timur. Berdasarkan hasil penelitian dan pengujian yang dilakukan, dapat disimpulkan bahwa stabilisasi menggunakan fly ash pada tanah lempung ini dapat memperbaiki sifat mekanis tanah. Dari hasil pengujian nilai kuat tekan yang paling efektif sebesar 4,041 gr/ $\mathrm{cm}^{2}$ pada penambahan fly ash $10 \%$ dari tanah asli, dengan presentase kenaikan sebesar $46,68 \%$ per $10 \%$ (1\% nya naik $4,67 \%$ ) dan tergolong tanah lempung sangat kaku. Penambahan fly ash pada tanah lempung akan mengakibatkan peningkatan daya dukung tanah yang sebanding dengan peningkatan kuat tekan tanah.

2. Menurut Hardiyatmo, Hary C. (1992). Mekanika Tanah 1, Jakarta : PT. Gramedia Pustaka Utama. Stabilisasi Tanah Dengan Menggunakan Fly Ash Dan Pengaruhnya Terhadap Nilai Kuat Tekan Bebas Hasil pengujian UCT sebagai berikut : Nilai qu tertinggi didapat dari tanah dengan kadar fly ash sebesar 20\% dengan lama pemeraman selama 21 hari yang menghasilkan nilai qu sebesar $2,55 \mathrm{~kg} / \mathrm{cm}^{2}$, meningkat sebesar $202,38 \%$ dari nilai terendah yaitu $1,26 \mathrm{~kg} / \mathrm{cm}^{2}$. Penambahan fly ash menaikan nilai batas plastis, batas cair. Nilai Indeks Plastisitas dan Berat Jenis mengalami penurunan seiring bertambahnya peresentase fly ash

3. Roseno Rahmadya, Reza. (2014). Pengaruh Penambahan Bahan Campuran (Dengan Slag Baja Dan Fly Ash) Pada Tanah Lempung Ekspansif Terhadap Nilai CBR Dan Swelling

\section{METODE}

\section{Tahapan Penelitian}

Tahapan penelitian yang digunakan adalah sebagai berikut :

1. Melakukan pengamatan langsung terhadap stabilitas tanah di wilayah SP 4 Kabupaten Sorong

2. Mengolah data dari hasil yang telah di dapatkan pada saat melakukan pengamatan langsung .

3. Mengidentifikasi dan menganalisa permasalahan stabilitas tanah. 
Semua metode penulisan dan analisa dalam artikel ilmiah ini merujuk pada panduan penulisan tugas akhir Fakultas Teknik Universitas Muhammadiyah Sorong tahun 2014 (Pristianto, Amri, \& Rusdi, 2014).

\section{REFERENSI}

1. Berry, Peter L. 1987 An Introduction to Soil Mechanics. England: Mc Graw- Hill Book Company

2. Soedarmo, Djatmiko. (1993). Mekanika Tanah 1,Malang : Kanisius. Terzaghi, Karl. (1967). Mekanika Tanah dalam Praktek Rekayasa. Terjemahan Ir. Bagus Witjaksono dkk. Jakarta Erlangga

3. Hardiyatmo, Hary C. (1992). Mekanika Tanah 1, Jakarta : PT. Gramedia Pustaka Utama.

4. Hardiyatmo, Hary C. (1994). Mekanika Tanah 2, Jakarta : PT. Gramedia Pustaka Utama.

5. Aridyanti, Tika. (2014). Pengaruh Penambahan Limbah Baja (Slag) Pada Tanah Lempung di Daerah Babat Lamongan Terhadap Nilai California Bearing Ratio (CBR) Test

6. Roseno Rahmadya, Reza. (2014). Pengaruh Penambahan Bahan Campuran (Dengan Slag Baja Dan Fly Ash) Pada Tanah Lempung Ekspansif Terhadap Nilai CBR Dan Swelling

7. Cristanto, Andy. (2003). Pengaruh Fly Ash Terhadap Sifat Pengembangan Tanah Ekspansif Bonar, Rudy (2015). Stabilisasi Tanah Lempung dengan Menggunakan Abu Sawit Terhadap Nilai Kuat Tekan Bebas Smith, M. J. (1984) Mekanika Tanah. Terjemahan Ir. Elly Madyayanti. Jakarta : Erlangga

8. Wesley, L.D. (1988). Mekanika Tanah, Jakarta Selatan : Pekerjaan Umum. SNI 03-1742-1989, Metode pengujian tentang kepadatan ringan untuk tanah. 